RELATO DE CASO

ISSN 1677-5090

(C) 2018 Revista de Ciências Médicas e Biológicas

DOI: http://dx.doi.org/10.9771/cmbio.v17i3.23493

\title{
Sarcoidosis of the breast: an unusual clinical presentation
}

\author{
Sarcoidosis da mama: uma apresentação clinica não usual
}

\author{
Jozélio Freire Carvalho ${ }^{*}$, Cleófano Lima Ramos², Paulus Mascarenhas Ramos², Virginia Freitas de Sá \\ Oliveira², Danilo Barral de Araújo 3
}

\begin{abstract}
${ }^{1}$ Rheumatologist at the Aliança Hospital Medical Center, Free Professor at the University of São Paulo Adjunct Professor (Visitor) of the Health Sciences Institute of the Federal University of Bahia.; ${ }^{2}$ Mastology Division, Clínica de Oncologia (CLION), Salvador, Bahia.; ${ }^{3}$ Associate Professor I of Oral Biochemistry
\end{abstract}

\begin{abstract}
Introduction: sarcoidosis is a chronic systemic granulomatous disease of unknown etiology. The breast may be involved in less than 1\% of cases and often mimics carcinomas at clinical examination. Case report: herein, the authors report a 54-year-old woman who had history of erythema nodosum, had clinical presentation suggestive of mastalgia whose mammography and ultrasound showed bilateral unspecific heterogeneous parenchymal densities. Histopathological study revealed non-caseous giant cell granulomas. Specifically, serum levels of angiotensin-converting enzyme (ACE) were elevated and a CT scan showed small bilateral pulmonary nodules distributed along the pleura and bronchovascular bundles (perilymphatic pattern), however without enlarged bilateral hilar and mediastinal lymph nodes. The patient was treated with prednisolone and methotrexate, and is currently asymptomatic. Conclusion: breast involvement by sarcoidosis, although rare, should be considered when dealing with granulomatous lesions of the breast. Keywords: Sarcoidosis. Breast Sarcoidosis. Granulomatosus disease.
\end{abstract}

\begin{abstract}
Resumo
Introdução: a sarcoidose é uma doença granulomatosa sistêmica crônica de etiologia desconhecida. A mama pode ser envolvida em menos de $1 \%$ dos casos e, muitas vezes, imita os carcinomas ao exame clínico. Relato de caso: aqui, os autores relatam uma mulher de 54 anos que teve história de eritema nodoso, apresentou quadro clinico sugestivo de mastalgia, cuja mamografia e ultra-som apresentaram densidades parenquimatosas heterogêneas inespecíficas bilaterais. $O$ estudo histopatológico revelou granulomas de células gigantes não-caseosos. Especificamente, os níveis séricos de enzima conversora de angiotensina (ECA) estavam elevados e uma TC apresentou pequenos nódulos pulmonares bilaterais distribuídos ao longo da pleura e feixes broncovasculares (padrão perilinfático), porém sem gânglios bilaterais hilar e mediastinal. A paciente foi tratado com prednisolona e metotrexato, e atualmente está assintomática. Conclusão: o envolvimento mamário por sarcoidose, embora raro, deve ser considerado ao lidar com lesões granulomatosas da mama.
\end{abstract}

Palavras-chave: Sarcoidose. Sarcoidose da mama. Doença granulomatosa.

\section{INTRODUCTION}

Sarcoidosis is an idiopathic systemic inflammatory granulomatous disorder comprised of epithelioid and multinucleated giant cells with little necrosis. It usually involves the lungs and may also involve lymph nodes, skin, liver, spleen, eyes, phalangeal bones, and parotid glands. Breast involvement is extremely rare, but, when present, it could be confused with benign or, more important, malignant neoplasm.

There are about 29 cases of breast sarcoidosis until 1995 and they were reviewed by Donaldson et al. ${ }^{1}$ An additional study, in 2000 Ojeda et al. published a review with all 35 cases published from 1921 to $1997 .{ }^{2}$ After that, few other cases were added to the literature.

Since breast sarcoidosis is a very uncommon situation, the objective of this study was to describe one additional case of sarcoidosis of the breasts.

Correspondente/Corresponding *Jozélio Freire Carvalho-Ed: Av. Juracy Magalhães Jr., 2096, Consultório 405, 40 andar, Rio Vermelho Salvador - Bahia 41920-900 - Tel.: (71) 2108-4643 -E-mail: jotafc@gmail.com

\section{CASE REPORT}

A 54-year-old Caucasian female began with antecedents of erythema nodosum in 1990 with spontaneous resolution and uveitis in 1992. At that time, clinical and laboratory investigation was unspecific, with antinuclear and anti-dsDNA antibodies and syphilis serology which were negative. She was treated with colchicine and diphosphate of chloroquine with complete response. She had two sisters with history of uveitis. She complained in 2008 of mastalgia. She was under surveillance due to bilateral cysts of her breasts since 2002. General systemic physical examination was unremarkable except for the breast examination that demonstrated skin retraction on lower quadrants with irregular and thickness on left upper and lower quadrants of hr right breast and on all left breast, particularly in left upper quadrant measuring $1.5 \mathrm{~cm}$ in this left breast (Figure 1). Lymph nodes were normal. Mammography showed heterogeneity on glandular tissue. Ultrasound demonstrated bilateral unspecific heterogeneous parenchymal densities (Figure 
2). Breast ultrasound revealed heterogeneity on glandular tissue, without nodules or cysts and normal lymph nodes. A magnetic resonance image was performed and demonstrated areas of post-contrast enhancement in both breasts of not defined areas, with slowly and progressive curves of impregnation and some parts with plateau aspect. There were not subareolar, retromamary fat tissue, pectoral muscle or axillar lymph nodes alterations (Figure 3). A core biopsy guided by ultrasound was indicated and revealed numerous non-caseous giant cell Langerhans' granuloma with negative Mycobacterium and fungi, that were compatible with sarcoidosis (Figure 4). A computed tomography of thorax detected interstitial nodular process on peribronchovascular and subpleural regions, compatible with incipient pulmonary fibrosis. No enlargement of mediastinal lymph nodded were observed. She denied dyspnea, thoracic pain or cough. Laboratory exams showed normal cell blood count, biochemistry exams including calcium levels $(9.5 \mathrm{mg} / \mathrm{dL}$; normal 8.5 to $11 \mathrm{mg} / \mathrm{dL}$ ), C-reactive protein of $0.2 \mathrm{mg} / \mathrm{dL}$ (normal values $<1 \mathrm{mg} / \mathrm{dL}$ ), erythrocyte sedimentation rate of $3 \mathrm{~mm} / 1^{\text {st }}$ hour and an increased level of angiotensin converter enzyme of $144 \mathrm{U} / \mathrm{L}$ (normal: 35 to $90 \mathrm{U} / \mathrm{L}$ ), compatible with sarcoidosis, and globulins $3.2 \mathrm{~g} / \mathrm{dL}$ (normal: 1.5 to $3.0 \mathrm{~g} /$ $d L$ ). Antinuclear, anti-dsDNA and anti-CCP antibodies and rheumatoid factor were all negative. Serologies for HIV, hepatitis $B$ and $C$ and syphilis were also negative. Tuberculin test was no reactive. She was treated with prednisolone $20 \mathrm{mg} /$ day and methotrexate $10 \mathrm{mg} /$ week and obtained good response. She experienced rapid improvement of mastalgia and the breast skin lesions healed.

Figure 1 - Picture showing deformity on the skin left breast

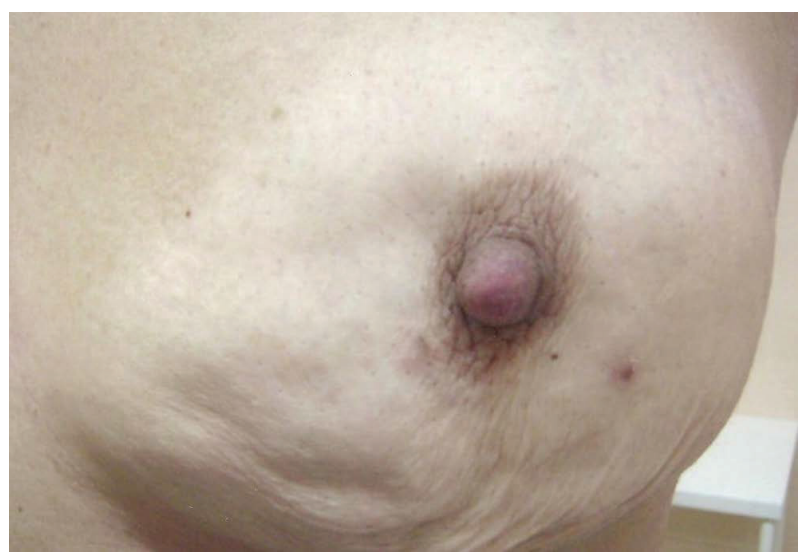

Source: From the authors
Figure 2 - Mammography demonstrating heterogeneity on glandular tissue
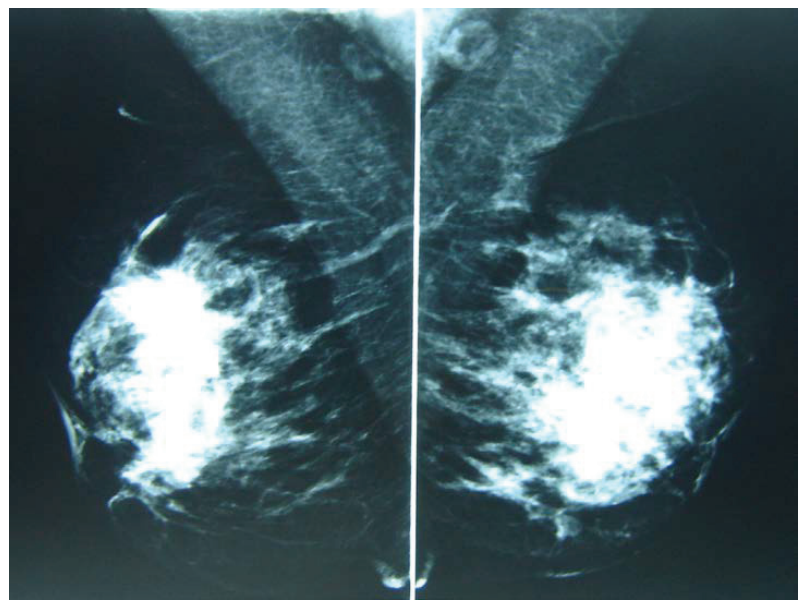

Source: From the authors

Figure 3-Histopathological analysis revealing granulomas with noncaseous necrosis on breast tissue

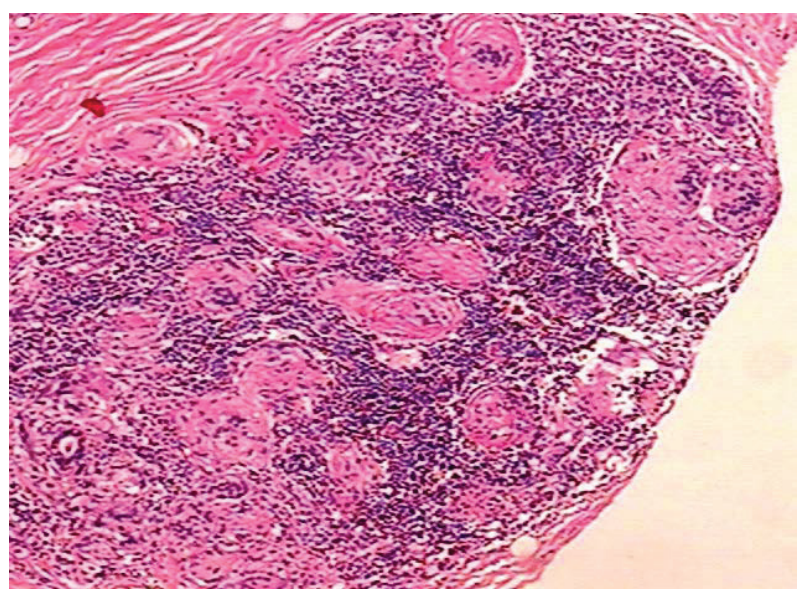

Source: From the authors

\section{DISCUSSION}

This article adds to the literature a new case of the uncommon condition of sarcoidosis of the breast.

Sarcoidosis is a chronic systemic autoimmune granulomatous disease of unknown etiology, which is characterized by the presence of non-caseous epithelioid granulomata with negative tuberculosis and fungi agents. This disease affects the lungs, lymph nodes, spleen, liver, skin, bones, muscles, eyes, central nervous system and salivary glands. Involvement of the breast is extremely rare, occurring in less than $1 \%$ of reported cases. ${ }^{3}$ In the majority of cases with breast involvement, other organs are already involved. Occasionally, and much rarely, breast involvement can be the initial site of the disease. ${ }^{1}$

Ojeda et al. ${ }^{2}$ reviewed the literature published between 1921 and 1997 and were able to find 35 cases of 
breast sarcoidosis. In seven cases, a breast mass was the initial manifestation of the disease. Clinically, sarcoidosis may present as a non-tender mobile mass. The borders of the lesion can be smooth or irregular. ${ }^{5}$

On mammography, the mass can appear well defined or with spicule. It may exist as a single mass or as multiple lesions. On ultrasound, a hypoechoic mass may show indistinct borders that cannot be differentiated from malignancy. ${ }^{1}$ Conversely, it can present as an intramammary lymph node or a granuloma. Ishimaru et al. ${ }^{3}$ described MRI findings of inhomogeneous signal intensity, irregular contours, rapid enhancement and an early "washout", similar to the changes seen in inflammatory lesions and in carcinoma of the breast.

On examination, sarcoidosis generally presents as a firm mass, with a tan cut surface. The borders of the lesion vary from well defined to irregular and indistinct. The size of the lesion is also varied, ranging from microscopic to $8 \mathrm{~cm} .^{4}$

The differential diagnoses of granulomatous mastitis include tuberculosis, fungal infections, and sarcoidosis. Tuberculosis of the breast is extremely rare and it was excluded to our case by the absence of caseous necrosis, negative tuberculin test and Ziehl-Neelsen stains for acid fast bacilli. In the same manner, fungi were eliminated by stains for fungi. Another important disease that was excluded was granulomatosis lobular mastitis, this disorder affects young females (17 to 42 years old) and it is linked to pregnancy, lactation and oral contraceptive use.

In our case, the thorax tomography was compatible with incipient fibrosis without mediastinal lymphade- nopathy. The literature reveals that patients with breast sarcoidosis have evidence for clinical or laboratory evidence of sarcoidosis elsewhere or have a previous history suggestive of sarcoidosis. ${ }^{6}$ In addition, angiotensin converter enzyme was high, which is classically compatible with sarcoidosis. These aspects were also observed in our patient who had erythema nodosum and uveitis more than 10 years before breast sarcoidosis diagnosis.

In summary, this case illustrates an unusual presentation of sarcoidosis with breast involvement. Sarcoidosis of the breast should be included into the differential diagnosis of patients with previous sarcoidosis or those with breast abnormalities.

\section{REFERENCES}

1. DONALDSON, B. A.; POLYNICE, A.; OLUWOLE, S. Sarcoidosis of the breast: case report and chart review. Am. surg., Atlanta, v. 61, p.778-780, 1995.

2. OJEDA, H.; SARDI. A.; TOTOONCHIE A. Sarcoidosis of the breast: implications for the general surgeon. Am. surg., Atlanta, v. 66, p.11441148, 2000.

3. ISHIMARU, K. et al. Sarcoidosis of the breast. Eur. Radiol., Berlin, supl. 3, p. S105-108, 2002.

4. BANIK, S. et al. Sarcoidosis of the breast. J. clin. pathol., London, v. 39, 446-448, 1986.

5. BÄSSLER, R.; BIRKE, F. Histopathology of tumour associated sarcoid-like stromal reaction in breast cancer. An analysis of 5 cases with immunohistochemical investigations. Virchows. Arch. A. Pathol. Anat. Histopathol., Berlin, v. 412, p.231-239, 1988.

6. RIGDEN, B. Sarcoid lesion in breast after probable sarcoidosis in lung. Br. Med. J., London, v.2, p.1533-1534, 1978.

Submetido em: 08/07/2017

Aceito em: 04/07/2018 